\title{
Enterococcus thailandicus
}

National Cancer Institute

\section{Source}

National Cancer Institute. Enterococcus thailandicus. NCI Thesaurus. Code C114243.

A species of facultatively anaerobic, Gram-positive, spherical or ovoid shaped bacteria arranged in pairs or chains, in the phylum Firmicutes. This species is nonmotile, non-spore forming, catalase negative, hydrolyzes arginine and esculin, but not starch or gelatin, weakly positive for blood hemolysis, does not reduce nitrate, and ferments glucose. E. thailandicus has been isolated from fermented sausages produced in Thailand and is not yet known to be pathogenic to humans. 